\title{
Effects of Increasing the Power of Retail Chains on Competitive Position of Wholesalers
}

\author{
Stipe Lovreta ${ }^{1}$, Jelena Končar ${ }^{2}$, Ljiljana Stanković3
}

${ }^{1}$ Faculty of Economics, University of Belgrade, Kamenicka 6, 11000 Belgrade, Serbia; slovreta@ekof.bg.ac.rs

${ }^{2}$ Faculty of Economics Subotica, University of Novi Sad, Segedinski put 9, 24000 Subotica, Serbia; jkoncar@ef.uns.ac.rs

${ }^{3}$ Ministry of Trade, Tourism and Telecommunications, Government of the Republic of Serbia, Nemanjina 22-26, 11000 Belgrade, Serbia; ljiljana.stankovic@mtt.gov.rs

\begin{abstract}
Highly noticeable processes of retail market concentration have marked the end of the last and the beginning of this century. The intensive development of retail chains and high-level of increasing of their power caused the shifting of powers, changes of positions and the establishment of new relationships between the members of marketing channels. Retailing revolution which makes substantial changes to former marketing channels is under way. A lack of understanding these changes is especially noticeable on the developing markets where large retail chains assume key roles in creating and managing the channels. Strengthening of their position is more than evident. The position of wholesalers in these trends, i.e. need for their intermediating role between producers and retailers, becomes especially interesting. The situation is alarming, primarily, in the field of food and other fast moving consumer goods, where the changes manifest themselves to a high extent and with special content. Wholesalers are facing a less significant role with growing retailers, which are constantly making more numerous and more complex demands of them. In such conditions, many wholesalers disappear from the market. However, wholesalers still have significant possibilities and advantages of cooperation with large retail chains, which can strengthen their position and ensure survival in the marketing channels. This study confirms it, by proving that increasing the power of retailers brings a higher level of satisfaction for wholesalers and that they achieve a higher level of satisfaction in doing business with large rather than with small and medium-sized retailers.
\end{abstract}




\section{Introduction}

Modern markets, both mature and consolidating ones, are characterized by intensive trends, which immensely changes positions and relationships between members in marketing channels. Due to the power of the changes those trends can surely be considered as a retailing revolution. Despite the fact that individual markets have their own specificities, all market economies are characterized by certain common processes. Parallel to the increase of retail market concentration and increase of market share of the individual retail chains, the power of retailers is constantly increasing compared to the power of the other members of marketing channels. Retail chains become gatekeepers for approaching consumers [6], and simultaneously, they become larger and more powerful, individually. Also, retail as a sector, both in national and global markets, becomes more powerful. As John Dawson [3] [4], one of most eminent theorists in this field, emphasizes in his works, retail is transforming from a reactive to a highly proactive economic sector. Retailers become considerably larger than all the other members of marketing channels, even more so than the producers themselves. In accordance with this, due to their enormous buying power, large market shares, and sophisticated managements, giant retailers are considered power retailers and category killers, which clearly shows their power and dominant position [18].

With an-ever-growing market share, there arises the opportunity for large retailers with large retail stores to demonstrate their buying power to producers and to their suppliers in general. In such conditions, the power imbalance between members within marketing channels creates the opportunity for more powerful members to act in an opportunistic manner and to impose force [1], which eventually can endanger cooperation and efficient functioning of marketing channels. The complex situation, produced by change in balance between the competitive power of retailers and wholesalers, is especially evident. Wholesalers find themselves in undesirable situations which can be handled only by a small number of them.

Primarily, less numbers of ever growing retailers, in all the markets, have begun to control approaches to consumers. On the other hand, they become more demanding towards their suppliers, in order to rationalize buying and logistic activities, but also to concentrate their buying power, retailers look for fewer larger suppliers which can cooperate with them [10]. They are intensively striving to establish control and power both in horizontal and vertical dimensions of marketing channels [20], thus becoming the primary initiator of the vertical integrations and cooperation processes.

Also, it is not in the wholesalers' favor, as Desai states [5], that all market players have a high-level of understanding that one more level in marketing channels, except when intermediary brings special contribution and lower costs, doubtlessly increases inefficiency and decreases profitability. In that sense, no one wants to have worse business results, especially retailers with significant market and 
negotiating power. These strong market players are gradually taking upon themselves distributive tasks and numerous functions, formerly traditionally performed by wholesalers and producers. In this situation, the most important question is which one of the players retain the authority of performing a sufficient number of functions, so that its membership and intermediating role in a certain channel is justified [18].

However, if they keep their position in marketing channels, as well as all the other suppliers, wholesalers will also face the fact that retail chains mercilessly use their increased negotiating power, based primarily on accumulated market power, to shift negotiating positions with suppliers in their favor and purchase products at the lowest prices possible. The negotiating power of retailers and their constant pressure to decrease transactional prices create for the opposite side a constant need to increase efficiency and effectiveness, but unfortunately, also often seriously endanger the survival of the suppliers themselves. In these kinds of situations, sellers usually participate in supply to the extent when their profits become negative, while the dominant buyer maximizes its profit [7]. However, many of them withdraw too late. Wholesalers are especially exhausted by these situations, from which many of them never recover.

On the other hand, it is important to emphasize that by offering lower prices to its consumers, primarily based on achieved lower prices in purchases and increase of efficiency, and by ensuring a higher level of services in comparison to their competitors, large retail chains can continue to spill market share over into their favor. In this way they, also, contribute to a decrease in the number of small and medium-sized, classical, retailers which not only represent the wholesalers, but also the producers, and traditionally close a less demanding marketing channel, in which they can achieve significantly higher differences in prices and compensate that which was lost in competition with retail giants. In relation to that, small and medium-sized traders are undoubtedly very important for every market. For sure, the support policy connected with them, should be focused on: a) the enhancement of competitiveness, and b) innovation development [9]. At the same time, the most important areas for them to develop, are those such as cost management, trade and marketing, production, technical development and finances [12]. And, there is no time to lose.

In any case, in accordance with Maruyama [15], the modern changes in structure of the wholesale sector and in the position of wholesalers in marketing channels can be seen as a consequence of three most important factors:

- changes in retail structure which have directly influenced the changes in wholesale

- intensive development of informational technologies in distribution ("points of sale" system, electronic data exchange system and alike); and 
- application of new strategies of distribution, such as supply chain management and strategic alliance between producers and distributors with implementation of efficient consumer response systems, logistics reforms and changes in supply management.

It is obvious that wholesale sector, parallel to strengthening of large retail chains and disappearance of small and independent retailers from the market, in highly complex conditions, fights for its own survival and undergoes a strong transformation. Vulnerable wholesalers are, with the purpose to preserve and increase their role in marketing channels, enforced to apply new strategies and to make significant adjustments to the new situation. Their survival under modern conditions requires permanent dynamics so that, in accordance with the level of a given market development, a set of wholesale's roles substantially differs in transition, developing markets, industrialized ones and those with post-industrial market characteristics [19].

The changes have enforced the wholesalers to undergo significant transformations and to find different strategies for strengthening position in modern marketing channels. Many of them have made radical changes in their marketing behavior, and that as a precondition for survival within the market. Specialization and focus on the services they provide have become their basic advantages, and they keep on strengthening their position by finding new innovative ways to implement these [17]. Many market players have become aware of the fact that the flow of goods through the existing channels with more wholesale levels can be the least expensive way for marketing goods and services [8]. Today, along with other usual wholesale services, institutional wholesalers provide support, even to the largest retailers, and primarily they provide information on supply and demand trends on the market. They are aware of different situations. One of the most important is that a large informational gap between producers and retailers requires the intermediation by wholesalers so as to bridge the gap, making the marketing channels longer, while, opposite to this, a small informational gap, due to the development of product brands and presence of big retailers, makes distributional channels shorter and leaves little space for intermediation [21].

In accordance with this, wholesalers search for their place in marketing channels. Maybe the most impressive example for "outsourcing" the management of certain categories of products is when strong retailers give this activity to the leading suppliers in a given field. A practice known as "category captainship" means that wholesalers, category captains, usually conduct analyses on category and provide retailers with a detailed plan which includes recommendations related to which brands should be included in category, how to define prices for each product individually, how much space to allocate to each brand and where to position each brand on the shelves [14].

And, in addition to this, long-term relationships between partners in marketing channels are becoming a more important part of a long-term strategy of any 
participant, which is particularly significant for wholesalers due to the specificity of their intermediating role [2]. Wholesalers, more than any other member of marketing channels in the current conditions, should be oriented to the development of long-term relationships, in accordance with their marketing orientation [11]. However, a precondition for the establishment of such cooperation is acceptance of the power imbalance. This is the first step towards successful building of mutual relationships between wholesalers and large retailers [10]. The best example of a very strong wholesale role in modern conditions is market of Japan in which large international retailers enter with a common desire to implement in this local market their original global distribution system, trade customs and business models. They are, primarily, interested in developing direct relationships with producers, i.e. with their suppliers, excluding the wholesalers, in order to avoid uncertainty and higher costs, which an additional intermediary can produce. However, when it comes to the Japanese market, they are relatively often enforced to change their patterns of conduct and use Japanese wholesalers [16]. Nishimura [16] states that, faced with specificities and complexity of distribution in Japan, many foreign retailers change their usual strategies, which Carrefour did soon after it entered the market, by deciding to rely on local wholesalers for goods originating from Japan.

Generally speaking, wholesalers in all markets do not favour the development of large retail chains and enforcement of their power. One can often hear the wholesalers, accustomed to cooperating with small, i.e. traditional retailers, criticizing the modern, huge, retailers and accusing them for the failure of a large part of institutional wholesalers. However, many proactive wholesale intermediary firms within the developed markets, and more often in the market of Serbia, find a way to turn the current situation to their advantage and use all the benefits that cooperation with large retailers provides. They are starting to observe strong retailers not as a danger, but as a huge opportunity to develop business.

\section{Objective and Hypotheses of the Research}

The subject of this research is the insufficiently known and rarely analyzed effects which modern changes in the sphere of retail cause to the competitive position of wholesalers. The aim is to evaluate the consequences of increasing the power of retailers on wholesalers, which requires thorough and comprehensive observation of positive and negative influences on the position and real interests of wholesalers. In order to enlighten the mentioned influences, we have conducted the researches which should confirm or disprove the defined hypotheses:

H1: Increasing the power of retailers brings a higher level of satisfaction for wholesalers in their business activities, and it is in the interest of large, but not of small wholesalers. 
H2: Wholesalers, in market conditions characterized by the presence of strong retail chains, express higher level of satisfaction in doing business with large retailers than with small and medium-sized ones.

A detailed survey on wholesalers' satisfaction in Serbia, in accordance with the defined elements of a business relationship, enlightens the level of wholesalers' satisfaction with doing business with other members in marketing channels in modern conditions characterized by increasing the power of retailers, with special emphasis on cooperation with large and with small and medium-sized retailers individually. The whole picture of that cooperation is completed by the survey of the satisfaction index for individual elements of business relationship of wholesalers with large and with small and medium-sized retailers. Apart from that, the concrete wholesalers' responses also contribute to the evaluation of the existing level of their satisfaction in doing business with large and with small and medium-sized retailers.

The results of this research point to the real impact of changes in relationships between members in marketing channels in the market conditions characterized by constant increase of the retail power. Thereby, the results especially emphasize the existence of positive impact those changes make on the performance of the activities in the trade sector of the economy. The results should redirect uncritical opinions away from accusing the more and more efficient modern retailers of the unfavourable competitive position of wholesalers, which, again, due to their insufficient proactive approach, in terms of adjusting to new competitive conditions on the market, lose their positions and disappear from the market.

\section{Research Methodology}

With a view to researching the effects of demonstration of large retailers power on wholesalers in the marketing channels, comprehensive studies have been conducted on the market of the Republic of Serbia. In accordance with the defined research methodology, the obtained results have been analyzed and the effects of increasing and usage of retailers' power on the position of wholesalers have been evaluated. The obtained results were basis for giving answers to research hypotheses.

Instead of the (hardly feasible) possibility to precisely measure the power of large retailers and give a precise evaluation of positive and negative effects of its use on wholesalers, attitudes, i.e. opinions of a certain number of wholesalers were taken into consideration. Surveys, with satisfying scope for the current conditions on the Serbian market, presented a relatively good picture on the significance and effects of increasing the power of retailers on the competitive position of wholesalers in the marketing channels. 
In order to perceive a new position of wholesalers and their relationship with other members in the marketing channels, satisfaction of wholesalers with doing business with other members in the marketing channels was determined by calculating satisfaction indices for each individual relationship. To test the defined hypotheses, it is essential to conduct deeper analysis by segmenting wholesalers and retailers into large and small and medium-sized ones, where the criterion of size was a number of employees (up to 200 employees for small and mediumsized and 200 employees for large ones).

Satisfaction indices of wholesalers were calculated for the following individual business relationships (ij): 1. wholesalers (all) with producers (1a); 2 . wholesalers (all) with large retailers (1b); 3. wholesalers (all) with small and medium-sized retailers (1c); 4. large wholesalers with producers (2a); 5. large wholesalers with large retailers $(2 b) ; 6$. large wholesalers with small and medium-sized retailers (2c); 7. small and medium-sized wholesalers with producers (3a); 8. small and medium-sized wholesalers with large retailers (3b); 9. small and medium-sized wholesalers with small and medium-sized retailers (3c).

With the purpose of calculating the satisfaction indices of wholesalers for the individual business relationship, nine key criteria $(\mathrm{k})$ (elements of a business relationship) were defined. These criteria were a basis for evaluating cooperation between the members and for each of the criteria, the survey respondents defined:

- relevance for cooperation - points from 1 to 10 ; and

- level of satisfaction with the existing cooperation (satisfaction rate) points from 1 to 5 .

The following table (Table 1) shows the elements of a business relationship which were used in the questionnaire:

Table 1

Elements of a business relationship - criteria $(\mathrm{k})$

\begin{tabular}{|c|l|}
\hline$(\mathbf{k})$ & Elements of a business relationship - criteria $(\mathbf{k})$ \\
\hline 1 & Prices, rebates and additional payments \\
\hline 2 & Terms of payment (due to date) and regularity of payments \\
\hline 3 & Sales potential \\
\hline 4 & Range of assortment \\
\hline 5 & Activities and costs to be borne by a concrete member \\
\hline 6 & Cooperation in terms of promotional and other marketing activities \\
\hline 7 & Data exchange and electronic communication \\
\hline 8 & Level of trust \\
\hline 9 & Potential for development and possibility of a long-term partnership \\
\hline
\end{tabular}

Apart from this, significance of single elements of a business relationship was a subject to analysis as well, meaning that satisfaction index for all the elements of a business relationship was calculated individually for relationships of wholesalers 
with large retailers and with small and medium-sized retailers. Within the obtained data processing, the first step was normalization of satisfaction rate $\left(V_{i j, k}\right)$ obtained for each element of a business relationship ( $\mathrm{k}$ ) individually, as follows:

$$
X_{i j, k}=100 / 4\left(V_{i j, k}-1\right),
$$

$(i=1,2$ or $3 ; j=\mathrm{a}, \mathrm{b}$ or $\mathrm{c} ; k=1,2, \ldots, 9)$

(in case that a wholesaler rated sales potential of a retailer with 5 , then a value obtained by normalization would be 100 , with $4-75$, with $3-50$, with $2-25$ and with $1-0)$.

Satisfaction index $X_{i j}$, which measures a relationship (ij), was calculated as a weighted average of the obtained normalized rates $X_{i j, k}$ by each criteria. Ponder was obtained rate of relevance for cooperation of certain criteria, i.e. rated elements of a business relationship (from 1 to 10). Calculating satisfaction index for each individual relationship was performed according to the formula for weighted average:

$$
X_{i j}=\frac{\sum w_{i j, k} X_{i j, k}}{\sum w_{i j . k}},
$$

where $W_{i j, k}$ stands for average ponders of a k-criteria of an individual relationship (ij).

The following table (Table 2) illustrates the procedure for calculating satisfaction index:

Table 2

Illustration of procedure for calculating satisfaction index

\begin{tabular}{|c|c|c|c|c|}
\hline $\begin{array}{c}\text { Elements of a } \\
\text { business } \\
\text { relationship - } \\
\text { criteria (k) }\end{array}$ & $\begin{array}{c}\text { Satisfaction } \\
\text { rate by criteria }\end{array}$ & $\begin{array}{c}\text { Normalization } \\
\text { of satisfaction } \\
\text { rate }\end{array}$ & $\begin{array}{c}\text { Relevance for } \\
\text { cooperation } \\
\text { by criteria }\end{array}$ & Result \\
\hline 1 & 3 & 50 & 8 & 400 \\
\hline 2 & 3 & 50 & 8 & 400 \\
\hline 3 & 3 & 50 & 10 & 500 \\
\hline 4 & 3 & 50 & 10 & 500 \\
\hline 5 & 3 & 50 & 8 & 400 \\
\hline 6 & 4 & 75 & 9 & 675 \\
\hline 7 & 2 & 25 & 7 & 175 \\
\hline 8 & 3 & 50 & 9 & 450 \\
\hline 9 & 3 & 50 & 10 & 500 \\
\hline Total & & & 79 & 4000 \\
\hline
\end{tabular}


Satisfaction index in the presented case values $4000 / 79=50.63$. The whole procedure provides the value of satisfaction index, which ranges from 0 to 100 , and the same methodology is also applied for calculating satisfaction index by the elements of a business relationship individually (by criteria individually) for the relationship of wholesalers with large retailers and with small and medium-sized retailers.

The research was conducted on a stratified and purposely (non-random) chosen sample. The sampling included 15 wholesalers who generate most of their turnover through selling to the retailers within the market of the Republic of Serbia. In the chosen sample, 4 wholesalers with more than 200 employees (large wholesalers) and 11 wholesalers with less than 200 employees (small and medium-sized wholesalers) were interviewed. On average, they co-operate with 290 suppliers and 3620 customers, where the average number of customers among the retailers is 3240. All the wholesalers focus on food and other fast moving consumer goods.

In defining the sample, the researchers took into consideration adequate geographic distribution, size of undertakings measured by the number of employees and turnover, as well as a group of products with the largest share in turnover of a selected wholesaler. The sampling included $60 \%$ of turnover of food and other fast moving consumer goods which is generated in the wholesalerretailer relation within the Serbian market. The basic method used for obtaining the data from wholesalers was a direct personal interview (face-to-face) which was guided by a pre-defined questionnaire, during the first quarter of 2013. The data collected within the conducted survey research were processed and analyzed using statistical program SPSS 15.0.

\section{Research Results}

In the questionnaire they filled out within the conducted survey research, the wholesalers, primarily, determined the relevance for cooperation of each offered element of business relationship with producers and, separately, with retailers. After that, they rated the level of current satisfaction within the existing business relationships with producers, and, separately, with large and with small and medium-sized retailers, based on the same elements.

According to the pre-defined methodology, and on the basis of the obtained rates, the average satisfaction indices of wholesalers in doing business with different partners in marketing channels were obtained. The results are presented in the following table (Table 3): 
Table 3

Average satisfaction indices of wholesalers in doing business with other members in marketing channels (sample size: 15 wholesalers)

\begin{tabular}{|c|c|c|c|}
\hline $\begin{array}{r}\text { Satisfaction of } \\
\text { With } \downarrow\end{array}$ & 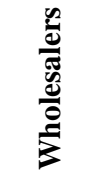 & 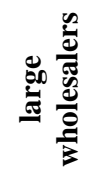 & 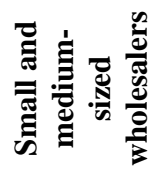 \\
\hline Producers & 67.23 & 77.78 & 63.26 \\
\hline large retailers & 62.99 & 70.54 & 58.98 \\
\hline $\begin{array}{l}\text { Small and medium- } \\
\text { sized retailers }\end{array}$ & 54.27 & 57.77 & 52.75 \\
\hline
\end{tabular}

Judging by the obtained results, in the current conditions of reached, relatively significant, level of concentration within the market of the Republic of Serbia, wholesalers, especially the large ones, express the highest level of satisfaction with doing business with producers, which indicates that there is one completely new position of wholesalers as intermediary and their current significant role for the producers. Apart from this, large wholesalers doubtlessly express significantly higher level of satisfaction with doing business with all other members in marketing channels, whether it concerns producers, or large retailers or small and medium-sized retailers, in comparison to small and medium-sized wholesalers.

Also, it is noticeable that wholesalers express significantly higher level of satisfaction with doing business with large retailers than with small and mediumsized ones. It is interesting enough that even small and medium-sized wholesalers achieve higher level of satisfaction with their relationship with large retailers than with small and medium-sized ones which were their traditional partners until now.

Again, there is a large difference in the satisfaction indices when observing the relationship between large wholesalers and large retailers, on one side, and the relationship between small and medium-sized wholesalers and small and mediumsized retailers, on the other side. The satisfaction index is significantly higher for the relationship between large wholesalers and large retailers.

The research results also gave a more detailed picture of business relationship of wholesalers with retailers per individual elements, which is presented in Table 4.

This table also shows the relevance of certain elements for wholesalers in terms of their business relationship with retailers, as well as satisfaction indices of wholesalers with large and with small and medium-sized retailers for those elements, with ranking. It is noticeable that the most relevant element for wholesalers, in their relationship with retailers, is "prices, rebates and additional payments", which includes sale prices and rebates given to retailers, as well as compensations to be paid additionally to retailers such as payments for "enlisting the products" and alike. 
Table 4

Satisfaction indices of wholesalers per the elements of a business relationship of wholesalers with large and small and medium-sized retailers (sample size: 15 wholesalers)

\begin{tabular}{|c|c|c|c|c|c|c|}
\hline \multirow[b]{2}{*}{ 范 } & \multirow{2}{*}{$\begin{array}{l}\text { Elements of a business relationship } \\
\text { of wholesalers with retailers }\end{array}$} & \multirow{2}{*}{ 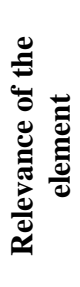 } & \multicolumn{2}{|c|}{$\begin{array}{l}\text { Large } \\
\text { retailers }\end{array}$} & \multicolumn{2}{|c|}{$\begin{array}{l}\text { Small and } \\
\text { medium- } \\
\text { sized } \\
\text { retailers }\end{array}$} \\
\hline & & & 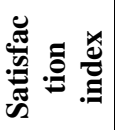 & $\stackrel{\mathscr{y}}{\ddot{E}}$ & 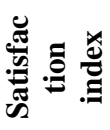 & 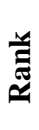 \\
\hline 1 & $\begin{array}{l}\text { Prices, rebates and additional } \\
\text { payments }\end{array}$ & 9.47 & 56.69 & 8 & 73.94 & 1 \\
\hline 2 & $\begin{array}{l}\text { Terms of payment (due to date) } \\
\text { and regularity of payments }\end{array}$ & 9.27 & 61.15 & 5 & 59.53 & 2 \\
\hline 3 & Sales potential of retailers & 8.47 & 74.61 & 2 & 56.89 & 4 \\
\hline $\begin{array}{c}4 . / \\
5 .\end{array}$ & Range of assortment of retailer & 7.67 & 79.13 & 1 & 58.04 & 3 \\
\hline $\begin{array}{c}4 . / \\
5 .\end{array}$ & $\begin{array}{l}\text { Activities and costs to be borne by } \\
\text { a concrete member }\end{array}$ & 7.67 & 58.70 & 7 & 55.00 & 5 \\
\hline 6 & Level of trust in retailer & 7.40 & 66.89 & 3 & 52.25 & 6 \\
\hline 7 & $\begin{array}{l}\text { Cooperation in terms of } \\
\text { promotional and other marketing } \\
\text { activities }\end{array}$ & 7.33 & 62.27 & 4 & 49.32 & 7 \\
\hline 8 & $\begin{array}{l}\text { Potential for development and } \\
\text { possibility of a long-term } \\
\text { partnership }\end{array}$ & 7.13 & 59.58 & 6 & 48.60 & 8 \\
\hline 9 & $\begin{array}{l}\text { Data exchange and electronic } \\
\text { communication }\end{array}$ & 5.60 & 47.92 & 9 & 34.82 & 9 \\
\hline & VERAGE SATISFACTION INDEX & & 62.99 & & 54.27 & \\
\hline
\end{tabular}

It is followed by "terms of payment (due to date)" and "regularity of payments". At the same time, those two elements offer to wholesalers in their relationship with small and medium-sized retailers the highest level of satisfaction, rank 1 and 2 , respectively. When it comes to large retailers, the satisfaction with these two elements is at a lower rank, while the highest rank, with the highest level of satisfaction, is related to the element "range of assortment of retailer," which is followed by "sales potential of retailer". However, it is highly significant that only for the first element, which is related to prices, rebates and additional payments is the satisfaction index higher for small and medium-sized retailers than for large ones, while for all other elements the significant advantage, in terms of the obtained satisfaction indices, is on large retailers' side. This finally leads to decisively higher average satisfaction indices for the relationship of wholesalers with large retailers. 
However, the concrete responses that wholesalers gave to the precise questions in connection to their attitudes about doing business with large and with small and medium-sized retailers make the picture of the current situation whole (Table 5):

Table 5

Concrete wholesalers' responds to the questions related to doing business with large and with small an medium-sized retailers (sample size: 15 wholesalers)

\begin{tabular}{|l|c|c|}
\hline \multicolumn{1}{|c|}{ Questions } & \multicolumn{2}{c|}{ Responses } \\
\hline $\begin{array}{l}\text { Do you prefer doing business } \\
\text { with large, modern, retailers or } \\
\text { with small and medium-sized, } \\
\text { traditional, retailers (who do you } \\
\text { rather choose for a partner)? }\end{array}$ & $\begin{array}{c}\text { With large, } \\
\text { modern, retailers }\end{array}$ & $\begin{array}{c}\text { With small and } \\
\text { medium-sized, } \\
\text { traditional, retailers }\end{array}$ \\
\cline { 2 - 3 } $\begin{array}{l}\text { Do you think that development of } \\
\text { retail chains is in your and } \\
\text { interest of other wholesalers? }\end{array}$ & $40.00 \%$ & $60.00 \%$ \\
\cline { 2 - 3 } & I think & I do not think \\
\hline
\end{tabular}

Although the level of satisfaction in doing business with large, modern retailers is significantly higher, only $40 \%$ of wholesalers responded that they rather choose for their partners large, modern, retailers. Apart from this, only 27\% think that development of large retail chains is in their interest and in the interest of other wholesalers, while $73 \%$ of them believe the opposite.

\section{Testing the Hypotheses}

Researches have confirmed the first hypothesis that "increasing the power of retailers brings a higher level of satisfaction for wholesalers in their business activities, and it is in the interest of large, but not of small wholesalers". Average satisfaction indices have shown a very high-level of satisfaction of wholesalers with their business relationship with producers, which confirms that, in conditions of ever growing retail market concentration, producers find the wholesaler's role very important, as well as that wholesalers are relatively satisfied with the way producers treat them. The t-test assesses that the level of satisfaction of wholesalers with their business relationship is significantly higher ( $\mathrm{t}=2.868$ (prob. 0.021)), so that we can accept the first hypothesis.

Also, when observing their satisfaction, on one hand, with large, and on the other hand, with small and medium-sized retailers, we notice a considerably higher level of satisfaction of large, but also of small and medium-sized, wholesalers with relationship with large retailers, in comparison to relationship with small and medium-sized retailers. However, these two groups of wholesalers do not show statistically significant differences in satisfaction with relationships with large retailers $(\mathrm{t}=1.706$ (prob. 0.126)), while the level of satisfaction with the cooperation with small retailers is significantly higher in large wholesalers $(\mathrm{t}=$ 2.704 (prob. 0.027)). 
Level of satisfaction of large wholesalers is in all cases, i.e. in their relationship with producers, with large retailers, but also with small retailers, significantly higher than the satisfaction that small and medium-sized wholesalers express for the same relationships. Generally, the lowest level of satisfaction is expressed by small and medium-sized wholesalers in terms of doing business with small and medium-sized retailers.

Researches have also confirmed the second hypothesis that "wholesalers, in market conditions characterized by the presence of strong retail chains, express a higher level of satisfaction in doing business with large retailers than with small and medium-sized ones". Average satisfaction index of wholesalers with their relationship with large retailers is on a significantly higher level than their average satisfaction index with the relationship with small and medium-sized retailers. This difference in the higher level of satisfaction of wholesalers business with large retailers is statistically significant $(t=2.273$ (ver. 0.053$)$ ), so that we can accept the second hypothesis.

Also, if we observe individual elements of a business relationship, we will notice that satisfaction indices for almost all the elements are on a significantly higher level for relationship of a wholesaler with large retailers. The only element which has the satisfaction level higher for the relationship of a wholesaler with small and medium-sized retailers is the element, which is currently the most important element of business relationship and it is related to prices, rebates and additional payments. When it comes to this element, the great advantage is on the small and medium-sized retailers' side.

However, concrete responses of wholesalers and an insufficient percentage of those wholesalers which rather choose large retailers for their partners and consider that the development of large retail chains is in their interest, indicate a very difficult situation in wholesale sector. Those wholesalers which are successful importers or distributors of relatively strong brands, or those specialized in specific product groups, generally prefer cooperation with large, modern retailers and consider the development of retail chains to be in their interest. It seems that they are more willing to rise to the new challenges. Opposite to this, the wholesalers with a wide range of assortment fear more of the future that surrounds the development of the retail giants and growth of their power.

Although the cooperation with large retail chains brings a higher level of satisfaction to wholesalers, it is obvious that the insufficient percentage of wholesalers within the observed market of Serbia has transformed adequately and increased its efficiency and effectiveness in terms of adapting to the modern distribution demands which have been dictated by large retail chains. Judging by the obtained responses, it is evident that many of them identify opportunities and advantages of doing business with large retail chains, but only few of them do believe they can use it for their own development and long-term survival in marketing channels. 


\section{Conclusions}

It is evident that increasing the power of retailers makes numerous effects on the position of institutional wholesalers in marketing channels and sets new demands for this type of intermediary. In that sense, many effects can be considered as negative ones. However, the development of large retailers also brings numerous positive impacts on position of institutional wholesalers in marketing channels. This is even confirmed by the Serbian market, the market, which is, one could say, in the initial phases of an intensive transformation.

At any rate, position of wholesalers in marketing channels is significantly changing with the development of the retail market. Today, the existence of wholesalers in marketing channels depends on the level of efficiency and effectiveness they manage to reach in carrying out their distributive activities. If they want to participate in distribution, they still must offer services of superior quality and also undergo transformations and changes in accordance with the demands and intensive changes imposed by their partners. Wholesalers will be able to avoid the danger of elimination by focusing on constant adjustments to the changes, and by flexibility and innovation.

Wholesalers must put more intensive efforts in finding and developing new areas of work which will represent their specific advantages. If they want to avoid complete isolation from the marketing channels, in conditions when strong retail chains endeavor to cut out wholesalers as intermediaries, they must, primarily, impose their role to the producers themselves, by providing them assistance and benefits in different segments. In accordance with Katsikeas's [13] statements, the power of wholesalers towards producers is exactly in their informational power, referent power, i.e. in a position to be a leader of numerous activities, their professional knowledge and other legitimate sources of power. In that sense, today, in their efforts to strengthen their role in the conditions of modern distribution, wholesalers turn out to be a sort of marketing and informational centers, highly important for the functioning of a channel as a whole and its results. The one which possesses relevant information on supply and demand can benefit from a direct inclusion in distributive process. And, this is the key characteristic of wholesale: to converse information into a profit.

Need for intermediation for producers, for large retailers, and certainly for small and medium-sized retailers, the one which would perform wholesale functions exists both on the market of Serbia and on the markets of the most developed countries. However, the question is if there are adequate partners on wholesalers side which can guarantee mutual success. Wholesale intermediaries which are able to meet the challenges imposed by a modern, highly concentrated retail market, will have a higher level of satisfaction in these conditions and will use numerous advantages offered by cooperation with modern, more efficient and effective retail chains. Still, it is hard to enter into the circle of winners, and even harder to last there. 


\section{References}

[1] Belaya, V., Hanf J. H. (2009) „The Two Sides of Power in Business-toBusiness Relationships: Implications for Supply Chain Management", The Marketing Review, Vol. 9, No. 4: 361-381

[2] Black, S. G. (2010) „Relationalism: A Vintage But Sound Concept in Distribution Channel Relationships“, Atlantic Economic Journal, No. 38: 245-246

[3] Dawson, J. (2004) „New Cultures, New Strategies, New Formats and New Relationships in European Retailing: Some Implications for Asia ”, Journal of Global Marketing, Vol. 18, No. 1-2: 73-97

[4] Dawson, J. A., Findlay, M. A., Sparks, L. (2008) „The Retailing Reader“, Routlage, USA and Canada

[5] Desai, P., Koenigsberg, O., Purohit, D. (2004) „Strategic Decentralization and Channel Coordination“, Quantitative Marketing and Economics, No. 2: $5-22$

[6] Dobson, P., Waterson, M., Davies, S. (2003) „The Patterns and Implications of Increasing Concentration in European Food Retailing“, Journal of Agricultural Economics, Vol. 54, No. 1: 111-125

[7] Ertek, G., Griffin, M. P. (2002) „Supplier - and Buyer - Driven Channels in a Two-Stage Supply Chain“, II E Transactions, Vol. 34, No. 2: 691-700

[8] Flath, D., Nariu, T. (2008) „The Complexity of Wholesale Distribution Channels in Japan“, The Japanese Economy, Vol. 35, No. 2: 68-86

[9] Hadžić, M., Pavlović, P. (2012) „Serbian Small and Medium-sized Enterprises in Times of Crisis", Acta Polytechnica Hungarica, Vol. 9, No. 3: $45-64$

[10] Hingley, K. M. (2005) „Power Imbalance in UK Agri-Food Supply Channels: Learning to Live with the Supermarkets“, Journal of Marketing Management, No: 21: 63-88

[11] Human, G., Peter, N. (2010) „Relationship and Innovation Orientation in a Business-to.Business Context", South African Journal of Business Management, No. 41 (4): 59-70

[12] Kadocsa, G., Francsovics, A. (2011) „Macro and Micro Economic Factors of Small Enterprise Competitiveness", Acta Polytechnica Hungarica, Vol. 8, No. 1: $23-40$

[13] Katsikeas, C., Goode, M., Katsikea, K. (2000) „Sources of Power in International Marketing Channels“, Journal of Marketing Management, No. 16: $185-202$ 
[14] Kurtuluş, M., Toktay, L. B. (2011) „Category Captainship vs. Retailer Category Management under Limited Retail Shelf Space“, Production and Operations Management, Vol. 20, No. 1: 47-56

[15] Maruyama, M. (2004) „Japanese Distribution Channels“, The Japanese Economy, Vol. 32, No. 3: 27-48

[16] Nishimura, J. (2004) „The Linkage of Trades in Terms of Wholesale Business Formats in Japanese Distribution Systems“, Journal of Global Marketing, Vol. 18, No. 1/2: 167-186

[17] Rosenbloom, B. (2007) „The Wholesaler's Role in the Marketing Channel: Disintermediation vs. Reintermediation", Int. Rev. of Retail Distribution and Consumer Research, Vol. 17, No. 4: 327-339

[18] Rossenbloom, B. (2013) „Marketing Channels - A Management View", South-Western, New York

[19] Samli, A. C. (2007) „American Wholesaler: Quo Vadis?“, Journal of Marketing Channels, Vol. 14, No. 3: 93-101

[20] Thomas, R. A., Wilkinson, J. T. (2011) “The De-Devolution of Marketing Is America's Marketing Model Fighting Hard Enough to Keep Up?", Marketing Management, spring: 19-25

[21] Torii, A., Nariu, T. (2004) „On the Length of Wholesale Marketing Channels in Japan“, The Japanese Economy, Vol. 32, No. 3: 5-26 